\title{
PENINGKATAN KETERAMPILAN BERBICARA MELALUI PENERAPAN METODE SHOW AND TELL SISWA SD NEGERI 3 BANJAR JAWA
}

\author{
Maya Hayatun Nupus ${ }^{1}$, , Desak Putu Parmiti ${ }^{2}$ \\ 1.Jurusan Pendidikan Guru Sekolah DasarUniversitas Pendidikan Ganesha Singaraja, Indonesia \\ 2 Jurusan Pendidikan Guru Sekolah DasarUniversitas Pendidikan Ganesha Singaraja, Indonesia
}

\begin{abstract}
Abstrak
Metode yang masih konvensional terutama dalam pembelajaran keterampilan berbicara seperti bercerita di depan kelas mengakibatkan rasa tidak percaya diri, perasaan malu-malu, serta ketidaksiapan siswa dalam bercerita. Melalui penelitian ini peneliti berusaha untuk mengungkapkan bagaimana meningkatkan keterampilan berbicara siswa kelas III sekolah dasar melalui penerapan metode Show and Tell yang merupakan metode dengan menunjukkan sesuatu kepada audiens (siswa) dan menjelaskan, mendeskripsikan, ataupun bercerita tentang hal-hal yang relevan dengan sesuatu yang ditunjukkan tersebut. Tujuan penelitian ini adalah: mengetahui penerapan metode Show and Tell dapat meningkatkan keterampilan berbicara siswa kelas III C SD Negeri 3 Banjar Jawa Tahun Ajaran 2017/2018. Desain penelitian ini adalah penelitian tindakan kelas dua siklus. Subjek penelitian adalah siswa kelas IIIC SD Negeri 3 Banjar Jawa Semester I Tahun Pelajaran 2017/2018. Metode pengumpulan data menggunakan tes evaluasi (lisan). Data dianalisis dengan menggunakan statistik deskriptif, metode analisis deskriptif kuantitatif dan peningkatan skor (Gn). Hasil analisis data menunjukkan peningkatan presentase ketuntasan klasikal dalam keterampilan berbicara pada siklus I sebesar $81 \%$ ternyata mengalami peningkatan pada siklus II menjadi 94\%. Terjadi peningkatan dari prasiklus ke siklus I sebesar

\begin{tabular}{l} 
Keywords: \\
\hline keterampilan \\
berbicara, show and \\
tell)
\end{tabular}

tell)
\end{abstract}

\section{PENDAHULUAN}

Berbicara merupakan suatu keterampilan, dan keterampilan tidak akan berkembang kalau tidak dilatih secara terus menerus. Keterampilan berbicara merupakan suatu keterampilan berbahasa yang perlu dikuasai dengan baik. Karena sebagai makhluk sosial, dalam kehidupan sehari-hari kita dituntut terampil berbicara untuk berkomunikasi dengan sesama. Seseorang yang terampil berbicara umumnya berani tampil di masyarakat, mudah bergaul, memiliki rasa percaya diri, dan dapat mempengaruhi orang lain. Apabila selalu dilatih, keterampilan berbicara tentu akan semakin baik. Sebaliknya, jika merasa malu, ragu, atau takut salah dalam berlatih berbicara, tentunya kepandaian atau keterampilan berbicara itu semakin jauh dari penguasaan. (Cahyani, 2012)

Sekolah dasar sebagai sekolah awal untuk melanjutkan ke jenjang yang lebih tinggi serta suatu saat para siswanya akan tumbuh dewasa dan hidup bermasyarakat, sudah barang tentu harus diberikan perhatian yang lebih, khususnya dalam pembelajaran keterampilan berbicara. Meskipun sulit, keterampilan berbicara sangat penting dikuasai oleh siswa. Mengingat pentingnya pengajaran keterampilan berbicara, kurikulum mencantumkan tujuan pengajaran bahasa yang cenderung ke arah keterampilan berbahasa, termasuk keterampilan berbicara. (Budiningsih, 2005)

Keterampilan berbicara dalam mata pelajaran bahasa Indonesia mengarahkan setiap siswa untuk meningkatkan kemampuan berkomunikasi secara lisan dengan baik dan benar di hadapan publik. Untuk mencapai hal tersebut, tentu siswa juga dituntut terampil berbicara dalamproses pembelajaran. Parasiswa harus mampumengutarakan gagasan ataupun pendapatnya. Mereka juga harus dapat menjawab pertanyaan atau mengajukan pertanyaan dengan baik selama pembelajaran berlangsung. Begitu pula dalam bercerita, siswa harus mampu bercerita dengan baik dan percaya diri 
karena bercerita merupakan salah satu keterampilan berbicara yang sangat penting untuk melatih komunikasi dan keberanian tampil di hadapan publik. (Mudini, 2009)

Berbicara pada dasarnya adalah menyuarakan kata hati, ide, pikiran, dan gagasan. Dengan demikian, hubungan antara suara yang keluar dengan apa yang ada dalam hati atau otak erat sekali (Rohim, dkk 2009: 37). Dalam Kamus Bahasa Indonesia (2008: 215) dinyatakan bahwa berbicara adalah berkata, bercakap, berbahasa, atau melahirkan pendapat (dengan perkataan, tulisan, dsb.) atau berunding. Tarigan (2008: 16) mengatakan bahwa berbicara adalah kemampuan mengucapkan bunyibunyi artikulasi atau kata-kata untuk mengekpresikan, menyatakan, serta menyampaikan pikiran, gagasan, dan perasaan. Sejalan dengan Tarigan, Mudini dan Salamat Purba (2009: 3) mengatakan bahwa berbicara adalah kemampuan seseorang menyampaikan pikiran, gagasan, dan perasaan dengan menggunakan bahasa lisan. Demikian juga Djago Tarigan (1991: 132) mengatakan bahwa berbicara adalah keterampilan menyampaikan pesan melalui bahasa lisan.

Beberapa pendapat di atas dapat disimpulkan bahwa berbicara itu lebih daripada sekadar mengucapkan bunyi-bunyi atau kata-kata saja, berbicara merupakan realisasi pikiran, gagasan, atau perasaan yang disampaikan dalam bentuk ujaran kepada orang lain untuk mencapai tujuan tertentu.

Tujuan utama dari berbicara menurut Tarigan (2008: 16) adalah untuk berkomunikasi. Agar dapat menyampaikan pikiran secara efektif, seyogianyalah sang pembicara memahami makna segala sesuatu yang ingin dikomunikasikan. Pembicara harus mampu mengevaluasi efek komunikasinya terhadap pendengarnya dan harus mengetahui prinsip-prinsip yang mendasari segala situasi pembicaraan, baik secara umum maupun perorangan.

Kita sering menjumpai adanya berbagai macam nama berbicara seperti ceramah, diskusi, percakapan, wawancara, bercerita, dan sebagianya. Hal tersebut disebabkan oleh dasar pengelompokan berbicara yang berbeda-beda, seperti: situasi, tujuan, metode, jumlah penyimak, dan peristiwa khusus.

Selain itu Djago Tarigan (1991: 176) menjelaskan, disamping faktor pembicara dan pendengar ada dua faktor lain yang besar pengaruhnya terhadap efektivitas berbicara, yaitu situasi dan ragam bahasa. Selain itu Djago Tarigan (1991: 176) menjelaskan, disamping faktor pembicara dan pendengar ada dua faktor lain yang besar pengaruhnya terhadap efektivitas berbicara, yaitu situasi dan ragam bahasa.

Hambatan dalam kegiatan berbicara menurut Resmini (dalam Rohaeti 2011: 21) mengemukakan bahwa hambatan tersebut terdiri dari hambatan yang datangnya dari pembicara sendiri (internal) dan hambatan yang datangnya dari luar pembicara (eksternal).

Subana dan Sunarti (2000: 217-218) menjelaskan aktivitas pembelajaran berbicara dapat dilakukan dengan tiga macam teknik, yaitu teknik terpimpin adalah teknik pembelajaran berbicara yang dilakukan dengan cara meminta siswa untuk mengujarkan sesuatu yang sama persis dengan contoh yang sudah ada, teknik semi terpimpin adalah teknik pembelajaran berbicara yang dilakukan dengan cara meminta siswa untuk mengujarkan/memaparkan sesuatu secara material sudah ada. Melalui teknik ini, siswa diberi kebebasan untuk mengembangkan paparan bahasa sesuai dengan tingkat kemampuan mereka, dan teknik bebas adalah teknik pembelajaran berbicara yang bebas dilakukan dengan cara meminta siswa untuk memaparkan sesuatu secara bebas, tanpa bahan yang ditentukan atau tanpa bimbingan dan pancingan tertentu. Ketiga teknik pembelajaran itu dapat diarahkan pada peningkatan keterampilan melakukan aktivitas berbicara, baik yang bersifat individual maupun kelompok.

Ada beberapa metode yang dapat diterapkan dalam pengajaran berbicara diantaranya sebagai berikut: Ulang-ucap; Lihat-ucapkan; Memerikan; Menjawab pertanyaan; Bertanya; Pertanyaan menggali; Melanjutkan; Menceritakan kembali; Percakapan; Parafrase; Reka cerita gambar; Bermain peran; Wawancara; dan Memperlihatkan dan bercerita (Show and Tell) (Cahyani, 2012: 95).

Keterampilan berbicara merupakan keterampilan berbahasa yang kompleks, yang tidak hanya mencakup persoalan ucapan/lafal dan intonasi. Berbicara di dalam bahasa apapun selalu menyangkut pemakaian ungkapan 'idiom' serta berbagai unsur bahasa dan nonbahasa. Karena itu evaluasi keterampilan ini seringkali menimbulkan kesulitan bagi guru. Aspek-aspek yang dinilai melalui tes berbicara mencakup ketepatan lafal, kejelasan ucapan, kelancaran, dan intonasi (Akhadiah, dkk 1991: 145).

Show and Tell adalah kegiatan show atau menunjukkan sesuatu kepada audiens dan tell menjelaskan atau mendeskripsikan sesuatu itu. Deskripsi dalam hal ini meliputi bentuk, warna, ukuran, komposisi, dan guna unsur. Tell dalam Show and Tell juga mengandung pengertian menjelaskan, yakni menjelaskan asal muasal benda yang ditunjukkan, menjelaskan fungsi benda secara umum, dan bahkan menjelaskan arti pentingnya benda bagi diri sendiri dan orang lain (Musfiroh, 2011: 5). Rohaeti (2011: 25) juga menjelaskan bahwa Show and Tell adalah kegiatan dalam pembelajaran yang menunjukkan 
sesuatu benda/barang kepada audiens dan kemudian menjelaskan atau mendeskripsikan benda/barang tersebut.Lebih lanjut dalam en.wikipedia.org/wiki/Show_and_tell_(education) dijelaskan tentang Show and Tell sebagai berikut:

Show and Tell is showing an audience something and telling them about it. InNorth AmericaandAustralia, it is a common classroom activity at earlyelementary school, used to teach young children the skills ofpublic speaking. Usually, a child will bring an item from home and will explain to the class why they chose that particular item, where they got it, and other relevant information. Metode Show and Tell ini dapat disimpulkan sebagai suatu metode di mana siswa disuruh menunjukkan benda/barang yang mereka sukai, bisa dengan meminta mereka membawa benda/barang tersebut dari rumah dan kemudian bercerita tentang benda tersebut di depan kelas. Adapun tujuan pengenalan ataupun penerapan Show and Tell menurut Taher (dalam Musfiroh, 2011: 3) difokuskan ke dalam beberapa hal. Pertama, menarik minat anak pada permasalahan sosial, seperti hubungan perkerabatan, gotong royong, jual beli, pendidikan, kebersihan, kemiskinan, dan tolong menolong. Kedua, Show and Tell mendorong anak-anak untuk bekerja sama memecahakan masalah-masalah sosial, mendorong mereka untuk berbagi gagasan, dan belajar menentukan pilihan.Ketiga, Show and Tell mendorong anak belajar menerapkan strategi berbicara dalam kaitannya dengan interaksi sosial, yakni: 1) mengidentifikasi permasalaham yang akan dibawakan, 2) mengumpulkan informasi, 3) mencoba mengaitkan dengan masalah lain, 4) menyampaikan permasalahan ke khalayak teman sebaya, 5) mengembangkan rencana Show and Tell selanjutnya.

Terkait dengan kemampuan berkomunikasi, Show and Tell bertujuan untuk menumbuhkan kemampuan berbagi informasi melalui cara menunjukkan benda dan menceritakan hal ikhwal benda tersebut, meliputi bentuk, ciri, komponen, fungsi, dan manfaat benda

Show and Tell memiliki relatif banyak manfaat. Manfaat tersebut menurut Taher (dalam Musfiroh, 2011: 6-7) dapat dirinci setidak-tidaknya sebagai berikut: Show and Tell memungkinkan anak-anak memahami problem-problem sosial secara lebih baik, yang hal tersebut membantu pemahaman teoritis mereka; Terdorongnya sikap demokratis oleh pendidik melalui pendekatan partisipatoris dalam proses pembelajaran; Pendidik dan anak-anak memiliki kesempatan untuk melakukan refleksi implikasi pedagogik terhadap problematika sosial; dan Pendidik dapat meningkatkan proses pembelajaran yang membantu anak didiknya memperoleh keberanian dan hasrat untuk terlibat dalam permasalahan sosial.

Isjoni (2007) menjelaskan metode Show and Tell baik digunakan untuk mengungkapkan kemampuan, perasaan, dan keinginan anak untuk bercerita apa sajayang ingin diungkapkannya. Saat anak bercerita guru dapat melakukan asesmen untuk mengetahui perkembangan anaktersebut. Guru dapat melanjutkan topik yang dibicarakan anak tersebut untuk pembelajaran. Biasanya banyak anakmengungkapkan perasaannya melalui metode ini.

Menurut Sulistyo (2011) Metode Show and Tell ini juga dapat mendidik anak lain untuk memperhatikan dan memberikan apresiasi kepada anak yang sedang bercerita. Keterampilan lain yang terbina dari kegiatan ini adalah keberanian untuk bertanya. Setelah cerita selesai, anak-anak diberi kesempatan untuk bertanya. Kepada anak-anak ditanamkan pengertian yang sangat penting bahwa tidak ada pertanyaan yang jelek dan tidak ada jawaban yang salah. Anak yang bertanya berarti dia anak pintar, bukan sebaliknya. Kembali kepada tujuan semula dari kegiatan ini yaitu membina keterampilan wicara.

Show and Tell memiliki banyak keunggulan. Pertama Show and Tell mampu mengembangkan keterampilan berbicara atau oral language skill, dan sangat efektif untuk mengenalkan kemampuan public-speaking karena berkenaan dengan kemampuan bertanya dan berbicara dalam gramatika yang lengkap (speaking in complete sentences, asking questions).

Kedua, Show and Tell mampu mengembangkan keterampilan sosial dalam berbagai aspeknya, terutama listening attentively, dan speaking in turn.

Ketiga, Show and Tell mendorong anak untuk melakukan problem solving. Pada saat berbicara anak dituntut untuk mencermati setiap detil benda yang ditunjukkannya di hadapan publik anak. Anak sebagai pembicara dituntut menyusun informasi dengan relatif baik karena sesuai dengan benda yang ditunjukkan.

Keempat, Show and Tell memberi kesempatan anak untuk hands-on dengan berbagai benda yang hal ini penting untuk melatih kemampuan elaborasi dan inventori. Selain itu kegiatan dengan tangan juga terkait dengan materi keaksaraan melalui kegiatan asosiasi huruf awal (associating beginning letters) dan bunyi-bunyi dengan objek riil (sounds with real objects) (Musfiroh, 2011: 6).

Musfiroh (2011: 15) menjelaskan bahwa Show and Tell mensyaratkan guru atau pendidik berperan sebagai fasilitator, advisor, dan komunikator. Pendidik memfasilitasi anak agar memilih benda-benda yang akan digunakan dalam kegiatan Show and Tell, memberikan saran pada anak tentang materi dan isi Show and Tell, serta membantu anak mengkomunikasikan apa yang dipikirkan dan 
dirasakannya. Anak berperan sebagai penyampai pesan, pemilik pesan dan penyimak sebaya. Di dalam kegiatan Show and Tell, anak sebagai pelaku penyampai pesan (menunjukkan dan menceritakan suatu benda sesuai keperluan), anak pulalah yang memiliki pesan sehingga baginya bebas menunjukkan jati diri dan keinginannya. Public dalam Show and Tell adalah anak-anak lain di kelas atau komunitas tertentu.

Adapun langkah-langkah pelaksanaan Show and Tell adalah sebagai berikut: Pengenalan Show and Tell dengan penjelasan tentang tata cara pelaksanaan Show and Tell; Pemodelan oleh guru dengan menunjukkan pada anak bagaimana cara bershow and tell dengan benda pribadi, makanan, gambar-foto; Memberikan kesempatan kepada masing-masing anak untuk melakukan Show and Tell dalam waktu tertentu; Pada saat anak melakukan Show and Tell, guru atau observer membawa lembar observasi dalam bentuk checklist; Setelah melakukan Show and Tell, anak diberi kesempatan bertanya jawab. Guru perlu memfasilitasi, mendorong, dan membantu anak bertanya yang relevan dan menjawabnya dengan relevan pula. Guru perlu memfasilitasi agar tanya jawab berjalan interaktif

Kenyataan di lapangan menunjukkan keterampilan berbicara siswa sekolah dasar, tepatnya siswa kelas IIIC SD Negeri 3 Banjar Jawa masih ada beberapa siswa yang masih kurang dalam keterampilan berbicara. Umumnya, siswa mengalami kesulitan ketika diminta untuk bercerita atau sekadar bertanya. Pada saat pembelajaran berlangsung, beberapa siswa tersebut hanya duduk dan mendengarkan penjelasan dari guru. Rendahnya keterampilan berbicara siswa tersebut juga dapat dilihat dari hasil observasi siswa pada keterampilan berbicara, dari 32 siswa terdapat 5(16\%) siswa yang masih kurang dalam keterampilan berbicara dan 3(9\%) menunjukkan sangat kurang dalam keterampilan berbicara.

Salah satu metode pembelajaran yang dianggap mampu untuk mengatasi masalah tersebut adalah metode Show and Tell (memperlihatkan dan bercerita). Metode Show and Tellini adalah metode dengan menunjukkan sesuatu kepada audiens (siswa) dan menjelaskan, mendeskripsikan, ataupun bercerita tentang hal-hal yang relevan dengan sesuatu yang ditunjukkan tersebut. Dengan metode ini siswa dapat menyampaikan sebuah cerita ataupun pengalaman dengan bantuan media, baik gambar, foto kegiatan sehari-hari yang pernah dilakukannya ataupun benda/barang bermakna yang dimiliki oleh siswa. Metode ini diharapkan mampu mengeksplorasi keterampilan berbicara siswa dengan lebih baik. (Tarigan, 2008)

Mengingat pentingnya hal tersebut maka metode Show and Tell menjadi sebuah alternatif yang baik untuk diterapkan dalam meningkatkan dan mengembangkan keterampilan berbicara siswa dikelas IIIC. Hal itulah yang melatar belakangi peneliti untuk melakukan penelitian dengan judul "Peningkatan Keterampilan Berbicara Melalui Penerapan Metode Show and Tell (Memperlihatkan dan Bercerita) Siswa Kelas IIIC SD Negeri 3 Banjar Jawa Tahun Pelajaran 2017/2018.

Berdasarkan pembatasan masalah di atas, maka rumusan masalah yang dapat dirumuskan sebagai berikut. "Apakah penerapan metode Show and Tell dapat meningkatkan keterampilan berbicarasiswa kelas III C SD Negeri 3 Banjar Jawa Tahun Ajaran 2017/2018"?

Untuk mencapai proses dan hasil belajar yang bagus tidaklah semudah apa yang kita bayangkan. Sebab dalam mencapai hal tersebut perlu adanya metode-metode pembelajaran yang diterapkan guru, salah satu metode yang dapat diterapkan adalah metode Show and Tell. Sekalipun penerapan metode Show and Tell bukanlah satu-satunya faktor yang menentukan, namun metode Show and Tell ini merupakan salah satu metode pengajaran yang diterapkan untuk dapat meningkatkan keterampilan yang akan dikembangkan.

Metode Show and Tell merupakan salah satu metode yang dapat diterapkan dalam pengajaran berbicara. Dengan metode tersebut dapat membantu siswa untuk meningkatkan keterampilan berbicara. Diharapkan siswa lebih mudah mengungkapkan gagasan atau pikiran mereka secara lisan. Dengan demikian dapat dipahami bahwa penerapan metode Show and Tell dapat meningkatkan keterampilan berbicara siswa kelas IIIC SD Negeri 3 Banjar Jawa.

Penelitian ini bertujuan untuk mengetahui penerapan metode Show and Telldapat meningkatkan keterampilan berbicara siswa kelas III C SD Negeri 3 Banjar Jawa Tahun Ajaran 2017/2018.

\section{METODE}

Penelitian ini tergolong sebagai Penelitian Tindakan Kelas yang dilakukan untuk peningkatan keterampilan berbicara siswa kelas IIIC SD Negeri 3 Banjar Jawa Tahun Ajaran 2017/2018. Tindakan yang dilakukan dalam penelitian ini adalah dengan penerapan metode Show and Tell. Oleh karena itu, prosedur penelitian yang digunakan dalam penelitian ini adalah prosedur Penelitian Tindakan Kelas yang dilaksanakan dalam bentuk siklus.

Penelitian ini telah dilaksanakan selama tiga bulan yaitu bulan Agustus-Oktober pada Semester I Tahun Ajaran 2017/2018 dengan mengambil tempat di SD Negeri 3 Banjar Jawa Kecamatan Buleleng 
Kabupaten Buleleng. Subjek dalam penelitian ini adalah siswa kelas IIIC SD Negeri 3 Banjar Jawa yang berjumlah 32 siswa yang terdiri dari 13 siswa laki-laki dan 19 siswa perempuan.

Penelitian ini mengacu pada teori yang dikemukakan Kemmis dan McTaggart (Agung, 2010) yang masing-masing siklus terdiri dari empat tahap yaitu: (1) perencanaan tindakan; (2) pelaksanaan tindakan; (3) observasi atau evaluasi; dan (4) refleksi. Siklus ini dapat digambarkan sebagai berikut.

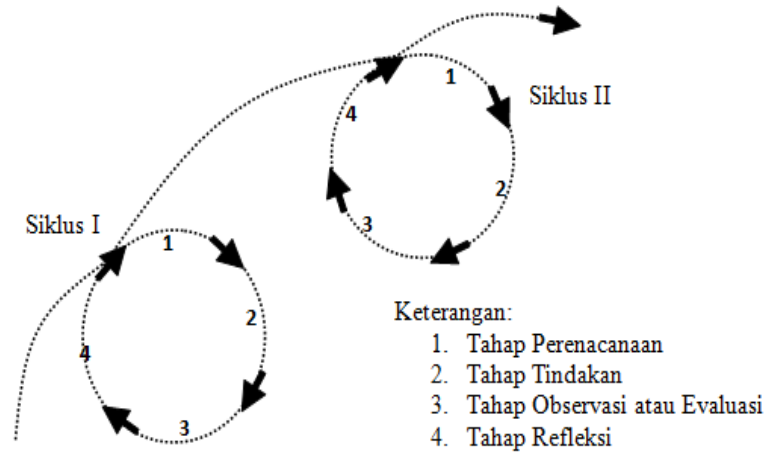

Gambar 01. Siklus PTK

Sumber: Agung (2005)

Penelitian ini dalam bentuk penelitian tindakan kelas. Penelitian tindakan kelas merupakan prosedur penelitian di kelas yang dirancang untuk menanggulangi masalah nyata yang dialami guru berkaitan dengan siswa di kelas itu (Santyasa, 2007). Tiap siklus terdiri dari empat tahapan yaitu: perencanaan tindakan, pelaksanaan tindakan, observasi atau evaluasi, dan refleksi.

Perencanaan pembelajaran siklus I disusun berdasarkan hasil studi pendahuluan yang diperoleh berdasarkan data bahwa siswa kelas IIIC SD Negeri 3 Banjar Jawa masih kurang dalam keterampilan berbicara terutama dalam menceritakan pengalaman mengesankan. Oleh karena itu, peneliti melakukan kolaborasi dengan guru kelas IIIC SD Negeri 3 Banjar Jawa dalam pembuatan rancangan tindakan, untuk memecahkan masalah yang dijumpai pada pembelajaran, khususnya dalam pembelajaran berbicara.

Pelaksanaan tindakan siklus 1 dilaksanakan pada hari Senin, 18 September 2017, berlangsung selama 4x35 menit dimulai pada pukul 09.30 Wita sampai dengan pukul 12.05 Wita dan pada hari Jumat, 22 September 2017, berlangsung selama 4x35 menit dimulai pada pukul 09.30 Wita sampai dengan pukul 12.05 Wita. Pada hari itu, siswa yang berjumlah 32 orang hadir semua. Pada pembelajaran siklus I difokuskan pada pembelajaran berbicara mengenai menceritakan benda yang ada di sekitar. Tahap ini dilakukan sejalan dengan situasi pembelajaran aktual di kelas. Peneliti melakukan pelaksanaan pembelajaran yang terdiri dari kegiatan awal, kegiatan inti, dan kegiatan penutup.

Siklus II dilaksanakan setelah selesai pelaksanaan evaluasi siklus I serta dilaksanakan refleksi terhadap proses belajar mengajar yang pernah dilakukan pada siklus I. Pelaksanaan siklus II ini dilaksanakan karena hasil pelaksanaan pada siklus I belum bisa dijadikan sebagai kesimpulan atas keberhasilan penelitian tindakan kelas. Pada siklus II langkah-langkah pelaksanaanya sama dengan langkah-langkah pada siklus I, namun kekurangan-kekurangan yang terjadi pada siklus I diperbaiki dan disempurnakan lagi untuk kemudian dilaksanakan pada siklus II.

Pelaksanaan tindakan siklus 2 dilaksanakan pada hari Sabtu, 30 September 2017, berlangsung selama 4x35 menit dimulai pada pukul 09.30 Wita sampai dengan pukul 12.05 Wita dan pada hari Senin, 1 Oktober 2017, berlangsung selama 4x35 menit dimulai pada pukul 09.30 Wita sampai dengan pukul 12.05 Wita. Pada hari itu, siswa yang berjumlah 32 orang hadir semua. Pada pembelajaran siklus 2 difokuskan pada pembelajaran berbicara mengenai menceritakan perubahan benda. Peneliti melakukan pelaksanaan pembelajaran yang terdiri dari kegiatan awal, kegiatan inti, dan kegiatan penutup.

Untuk mengumpulkan data dalam penelitian ini digunakan metode pengamatan menggunakan tes kinerja. Instrumen yang digunakan untuk mengukur keterampilan berbicara siswa berupa rubrik penilaian keterampilan berbicara. Rubrik penilaian ini untuk mendemonstrasikan atau mengaplikasikan pengetahuan yang telah diperoleh siswa dan menggambarkan suatu keterampilan siswa melalui suatu proses kegiatan atau unjuk kerja.

Setelah data dalam penelitian ini terkumpul maka selanjutnya dilakukan analisis data. Dalam menganalisis data ini digunakan metode analisis deskriptif kuantitatif. 
Agung (2005) menyatakan bahwa "metode analisis deskriftif kuantitatif adalah suatu cara pengolahan data yang dilakukan dengan jalan menyusun secara sistematis dalam bentuk angka-angka dan atau presentase mengenai suatu objek yang diteliti sehingga diperoleh kesimpulan umum".

Metode digunakan untuk penilaian keterampilan berbicara siswa dikonversikan kedalam penelitan acuan patokan (PAP) skala lima. Tingkatan keterampilan berbicara siswa dapat ditentukan dengan membandingkan M (\%) atau rata-rata persen ke dalam PAP skala lima.

Peningkatan keterampilan berbicara ditentukan dengan membandingkan nilai yang diperoleh pada prasiklus, siklus I sampai siklus ke-n.

Tindakan dapat dikatakan berhasil apabila kriteria keterampilan berbicara siswa minimal pada cukup lancar mengalami peningkatan ketuntasan klasikal keterampilan berbicara mencapai predikat minimal sedang dengan kriteria 0,30-0,69. Apabila indikator penelitian tidak tercapai maka akan dilakukan tindakan pada siklus selanjutnya.

\section{HASIL DAN PEMBAHASAN}

Pembelajaran untuk siklus I dilaksanakan di kelas IIIC SD Negeri 3 Banjar Jawa dengan 2 kali pertemuan pada tanggal 18 September dan 22 September 2017. Pada pertemuan pertama siswa diperkenalkan dengan metode Show and Tell dan pertemuan ke-2 dilakukan evaluasi keterampilan berbicara. Jumlah siswa adalah 32 orang dan seluruhnya mengikuti tes. Jumlah nilai yang diperoleh dari keseluruhan siswa adalah 2524 sehingga rata-rata nilai siswa adalah 78,86 memiliki kriteria keterampilan berbicara sedang. Jumlah skor terendah yang diperoleh siswa adalah 6 dengan nilai 38, dan jumlah skor tertinggi adalah 16 dengan nilai 100. Siswa yang tuntas 26 siswa dan yang tidak tuntas ada 6 siswa dengan persentase ketuntasan klasikal mencapai $81 \%$.

Hasil yang diperoleh tersebut belum mencapai indikator keberhasilan untuk keterampilan berbicara siswa yang telah ditetapkan dalam penelitian ini yaitu peningkatan keterampilan berbicara mencapai predikat minimal sedang dengan kriteria 0,30-0,69. Peningkatan masih dalam kategori rendah yaitu 0,24 sehingga masih perlu adanya peningkatan yang akan dilaksanakan pada siklus II.

Pencapaian hasil yang belum maksimal dalam siklus ini disebabkan oleh beberapa faktor seperti kurang seriusnya siswa dalam belajar, masih kurangnya keberanian siswa untuk maju dan becerita di depan kelas, serta banyak siswa yang kurang tau apa yang harus diceritakan sesuai dengan benda/barang yang mereka bawa sehingga cerita yang disampaikan terkesan meniru teman-temannya yang sudah maju sebelumnya.

Pembelajaran untuk siklus 2 dilaksanakan di kelas IIIC SD Negeri 3 Banjar Jawa dengan 2 kali pertemuan pada tanggal 30 September dan 2 Oktober 2017. Pada pertemuan pertama siswa diperkenalkan dengan metode Show and Tell dan pertemuan ke-2 dilakukan evaluasi keterampilan berbicara. Jumlah siswa adalah 32 orang dan seluruhnya mengikuti tes. Jumlah nilai yang diperoleh dari keseluruhan siswa adalah 2763 sehingga rata-rata nilai siswa adalah 86,34 memiliki kriteria keterampilan berbicara tinggi. Jumlah skor terendah yang diperoleh siswa adalah 10 dengan nilai 63, dan jumlah skor tertinggi adalah 16 dengan nilai 100. Siswa yang tuntas 26 siswa dan yang tidak tuntas ada 6 siswa dengan persentase ketuntasan klasikal mencapai 94\%.

Hasil yang diperoleh pada siklus 2 tersebut telah mencapai indikator keberhasilan untuk keterampilan berbicara siswa yang telah ditetapkan dalam penelitian ini yaitu peningkatan keterampilan berbicara mencapai predikat minimal sedang dengan kriteria 0,30-0,69. Peningkatan dalam kategori tinggi yaitu 0,76 .

Terlihat peningkatan rata-rata siswa yakni dari nilai rata-rata 78,86 pada siklus 1 meningkat menjadi 86,34 pada siklus 2, ketuntasan klasikal meningkat dari $81 \%$ pada siklus 1 menjadi $94 \%$ pada siklus 2, sehingga penelitian ini dikatakan berhasil.

Berdasarkan penjabaran di atas indikator keberhasilan penelitian yang meliputi prestasi yang berupa keterampilan berbicara siswa. Sehingga penelitian ini dikatakan berhasil dan penelitiaan ini hanya dilaksanakan dalam 2 siklus.

Penelitian Tidakan Kelas (PTK) ini dilaksanakan sebagai upaya untuk meningkatkan keterampilan berbicara siswa dengan menggunakan metode Show and Tell. Prosedur penelitian yang digunakan adalah prosedur penelitian tindakan kelas yang dilaksanakan dalam bentuk siklus. Dalam penelitian ini digunakan dua siklus yang masing-masing siklus terdiri dari dua kali pertemuan dan setiap siklus dilaksanakan sesuai dengan skenario yang telah dibuat dan memuat empat tahap kegiatan yaitu tahap perencanaan, tahap pelaksanaan tindakan, tahap observasi dan evaluasi yang dilanjutkan dengan tahap refleksi. 
Berdasarkan hasil analisis data pelaksanaan tindakan pada siklus I menunjukkan bahwa peningkatan keterampilan berbicara siswa belum mencapai indikator keberhasilan yang diinginkan. Terdapat kekurangan yang diperoleh dari hasil refleksi dalam proses pembelajaran pada siklus pertama, seperti siswa kurang serius dan sering membuat gaduh terutama ketika temannya sedang melakukan show and tell. Perlu adanya perbaikan pada kekurangan tersebut. Terlepas dari hal itu, pembelajaran berbicara melalui penerapan metode Show and Tell sudah menunjukkan adanya kelebihan yang terlihat dari beberapa hal, yaitu: Perhatian siswa terpusat pada materi yang dipelajari; Semangat dan antusiasme siswa yang tinggi serta tertarik mengikuti pelajaran; Guru sudah bagus dalam menjelaskan dan memberikan contoh penggunaan metode show and tell kepada siswa; dan Guru membimbing siswa dalam melakukan kegiatan show and tell.

Berdasarkan keterangan di atas mengenai adanya kekurangan yang perlu diperbaiki serta kelebihan yang perlu dipertahankan atau ditingkatkan, maka tindakan perbaikan yang dilaksanakan pada siklus 2 antara lain: Guru lebih mengawasi siswa agar lebih serius dalam belajar, tidak membuat gaduh, serta selalu memperhatikan dan menyimak temannya yang sedang melakukan show and tell; Guru lebih memotivasi dan meyakinkan siswa untuk berani mengajukan pertanyaan kepada guru maupun temannya serta berdiskusi dengan temannya; dan Guru hendaknya meminta siswa untuk mempelajari materi yang sudah dibahas serta memberikan pesan moral kepada siswa terkait materi pembelajaran.

Adapun hasil pembelajaran pada siklus 2 setelah melaksanakan tindakan perbaikan mengalami peningkatan dan terlaksana dengan baik. Hal ini terlihat dari peningkatan hasil keterampilan berbicara siswa, nilai rata-rata pada siklus 1 sejumlah 78,86 berkriteria sedang, persentase ketuntasan klasikal 81\% dengan predikat peningkatan rendah yaitu 0,24 meningkat menjadi rata-rata 86,34 berkriteria tinggi, ketuntasan klasikal mencapai 94\% dengan predikat peningkatan tinggi yaitu 0,76 pada siklus 2 .

Ringkasan dari hasil penelitian pada siklus I dan siklus II yang memuat rata-rata skor keterampilan berbicara siswa,ketuntasan klasial dan predikat peningkatan disajikan dalam tabel dan grafik

Tabel 1 Ringkasan Analisis Data Hasil Evaluasi dengan Penerapan Metode Show and Tell pada Siklus 1 dan 2 .

\begin{tabular}{cccc}
\hline Siklus & Hasil Keterampilan Berbicara \\
& Rata-rata & Ketuntasan Klasikal & $\begin{array}{c}\text { Predikat Peningkatan } \\
\text { (Gn) }\end{array}$ \\
\hline 1 & 78,86 & $81 \%$ & Sedang \\
2 & 86,34 & $94 \%$ & Tinggi \\
\hline
\end{tabular}

Adapun hasil pembelajaran pada siklus 2 setelah melaksanakan tindakan perbaikan mengalami peningkatan dan terlaksana dengan baik. Hal ini terlihat dari peningkatan hasil keterampilan berbicara siswa, nilai rata-rata pada siklus 1 sejumlah 78,86 berkriteria sedang, persentase ketuntasan klasikal $81 \%$ dengan predikat peningkatan rendah yaitu 0,24 meningkat menjadi rata-rata 86,34 berkriteria tinggi, ketuntasan klasikal mencapai $94 \%$ dengan predikat peningkatan tinggi yaitu 0,76 pada siklus 2

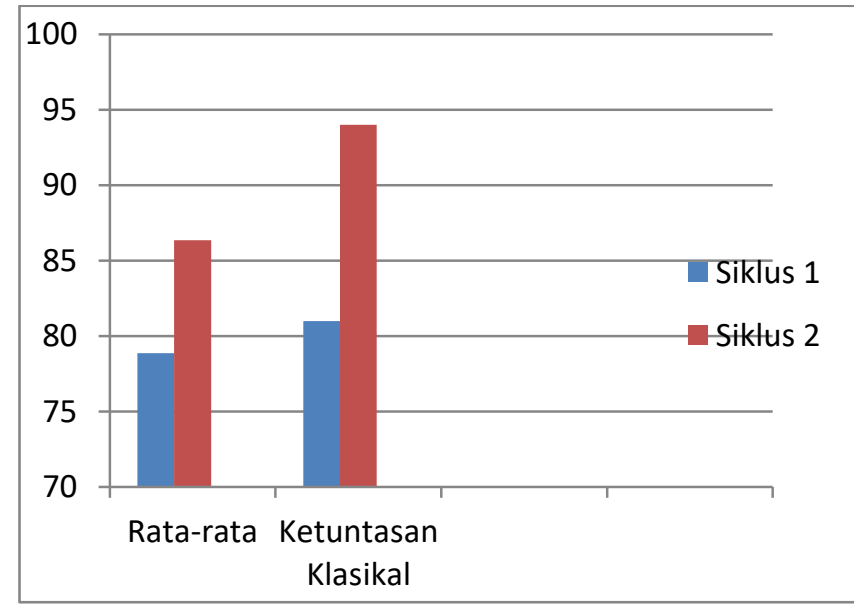

Gambar 2. Grafik Ringkasan Hasil Penelitian Siklus I dan Siklus I 


\section{SIMPULAN DAN SARAN}

Berdasarkan penelitian yang telah dilakukan pada siswa kelas IIIC SD Negeri 3 Banjar Jawa tahun pelajaran 2017/2018, maka dapat disimpulkan bahwa pembelajaran keterampilan berbicara melalui penerapan metode Show and Tell terbukti dapat meningkatkan keterampilan berbicara siswa kelas IIIC SD Negeri 3 Banjar Jawa tahun pelajaran 2017/2018.

Langkah-langkah pembelajaran metode Show and Tell yang dapat meningkatkan keterampilan berbicara siswa tersebut adalah: Pengenalan Show and Tell dengan penjelasan tentang tata cara pelaksanaan Show and Tell; Pemodelan oleh guru dengan menunjukkan pada anak bagaimana cara bershow and tell dengan benda pribadi, makanan, gambar-foto; Memberikan kesempatan kepada masingmasing anak untuk melakukan Show and Tell dalam waktu tertentu; dan setelah melakukan Show and Tell, anak diberi kesempatan bertanya jawab. Guru memfasilitasi, mendorong, dan membantu anak bertanya yang relevan dan menjawabnya dengan relevan pula.

Adapun saran-saran yang dapat peneliti sampaikan sehubungan dengan hasil penelitian ini adalah sebagai berikut.

Bagi siswa, jika menerapkan metode Show and Tell ini maka akan memberikan dampak baik dalam melatih dan mengembangkan keterampilan berbicara, maka diharapkan bagi.Ringkasan dari hasil penelitian pada siklus I dan siklus II yang memuat rata-rata skor keterampilan berbicara siswa ,ketuntasan klasial dan predikat peningkatan disajikan dalam tabel dan grafik dalam melatih dan mengembangkan keterampilan berbicara, maka diharapkan bagi siswa agar pembelajaran dengan metode ini benar-benar dapat dimanfaatkan sehingga dapat menumbuhkan keberanian tampil di depan kelas serta menumbuhkan kemampuan public-speaking sejak dini.

Bagi guru, jika guru dalam pembelajaran berbicara terutama dalam hal bercerita tidak menerapakan metode Show and Tell, maka para siswa akan mengalami kesulitan dalam memperoleh ide yang akan dijadikan topik pembicaraan, sehingga akan sulit untuk melatih keterampilan berbicara siswa, maka diharapkan bagi guru untuk dapat menerapkan metode Show and Tell sebagai salah satu metode pembelajaran alternatif dalam proses pembelajaran berbicara dan membuat pembelajaran lebih menarik.

Bagi peneliti, penerapan metode Show and Tell ini mampu menigkatkan keterampilan berbicara siswa, maka diharapkan bagi peneliti untuk mencoba mengembangkan penerapan metode Show and Tell pada materi yang lain dengan tujuan untuk meningkatkan keterampilan berbicara dan aktivitas belajar siswa, serta menjadikan kekurangan-kekurangan pada penelitian ini sebagai bahan pertimbangan dalam merencanakan penelitian, sehingga hasil penelitian menjadi lebih baik.

\section{DAFTAR PUSTAKA}

Agung, Anak Agung Gede. 2005. Metodologi Penelitian Pendidikan. Singaraja: FIP Undiksha.

Akhadiah, Sabarti, dkk. 1991. Bahasa Indonesia 1. Jakarta: Departemen Pendidikan dan Kebudayaan.

Akhadiah, Sabarti, dkk. 1991. Bahasa Indonesia 3. Jakarta: Departemen Pendidikan dan Kebudayaan.

Budiningsih, Asri. 2005. Belajar dan Pembelajaran. Jakarta: PT. Rineka Cipta.

Cahyani, Isah. 2012. Modul Pembelajaran Bahasa Indonesia. Jakarta: Kementerian Agama Republik Indonesia.

Fathurrohman. 2010. Strategi Belajar Mengajar (Melalui Penanaman Konsep Umum dan Konsep Islam). Bandung: Resika Aditama.

Mudini dan Salamat Purba. 2009. Pembelajaran Berbicara. Jakarta: Departemen Pendidikan Nasional.

Musfiroh, Takdiroatun. 2011. Show and Tell Edukatif: Panduan Pengembangan Social Skill Anak Usia Dini. Yogyakarta: Lokus

Rohim, Abdul, dkk. 2009. Kebahasaan. Jakarta: Departemen Pendidikan Nasional.

Subana, M dan Sunarti. 2000. Strategi Belajar Mengajar Bahasa Indonesia. Bandung: Pustaka Setia.

Tarigan, Henry Guntur. 2008. Berbicara: Sebagai Salah Satu Keterampilan Berbahasa. Bandung: Angkasa.

Tim Penyusun Kamus Pusat Bahasa. 2008. Kamus Bahasa Indonesia. Jakarta: Pusat Bahasa Departemen Pendidikan Nasional 